\title{
Conference Report: 'A Symposium on West Slavic Bible: Language and Style' (3 July 2020, Catholic Theological Faculty, Charles University, Prague)
}

\section{J I Ř Í H E DÁ N E K}

The international symposium at the Charles University Catholic Theological Faculty on 3 July 2020 with its subheading in four other West Slavic languages made quite clear theses five languages are to be spoken at the event. In fact, one contribution was made in yet another, specific dialect of a couple of villages at the very east of Germany, which was the first time ever that the dialect could be heard in a formal setting of an international convention. Admittedly, all these languages are fairly close but mutual comprehensibility is limited, especially for an untrained ear. That, however, was not the case of most of the attendance of several dozens which were Slavic and linguistic specialists on the Bible and translation and themselves active speakers of more these languages. This was the third time ${ }^{1}$ such a symposium was held at the venue, mainly thanks to doc. PhDr. Josef Bartoň ${ }^{2}$ who believes this interesting tradition will be able to continue next year.

The event was structured in four units, each with discussions, which continued informally even after the formal sessions ended.

\section{Nova}

'What should be corrected in the contemporary Upper Sorbian translation of the Holy Scriptures?'

Dr Daniel Dzikiewicz ${ }^{3}$ was able only to send a video (spoken in Upper Sorbian) dealing with specific issues of text (Gen 4:8; 22:1), errors, non-historical modernizations (2 Kings 19:15; Matth 1:18); philological issues (plusquamperfect in Luke 16:20; 11:22 and Hebr. dual in Gen 4:15c, both surprisingly not employed in Upper Sorbian) and theological issues (John 21:15-19, where the version employed a single verb throughout).

1 June 1, 2018 'The Language and Style of Bible Translating: Czech and Polish Perspectives' and June 7, 2019 'Bible Translation \& Language: Czech, Polish and Sorbian Metamorphoses'.

2 Department of Biblical Sciences and Ancient Languages, Catholic Theological Faculty, Charles University.

3 A Polish native, now an Assistant Professor in St. Joseph Theological Seminary, Vilnius, after having served as a priest in a central Upper Lusatian parish for ten years. 
Translating was also the topic of the next contribution:

'A new Slovak translation of the Gospel of John'

Doc. Róbert Lapko, ThD. et Ph.D., ${ }^{4}$ spoke (on video, due to illness) for the team of translators of the new Roman Catholic Translation to Slovak. The project, currently in its early stages, published so far only the Gospel of John in a working edition, ${ }^{5}$ well supplied with notes (some to explain particular translations) and ample references. The natural word order of Slovak is easy to listen to, which was the purpose.

The six translators (and twenty consultants) have also published proceedings on translation approaches ${ }^{6}$ to discuss their purpose to make a liturgical and textually reliable version of the Bible from the originals, with no regard to (Neo)Vulgate. It intends to be non-confessional and, apart from breaking away from the Latinized tradition, remarkable for its scholarly humility and the belief "the Bible is to be read through the Bible" (as doc. Lapka put it). The broad scope of the presentation was engaging for all the participants who regretted doc. Lapka had to be absent.

The first contribution presented in person was by Juliana Kaulfürstowa, M.A.: ${ }^{7}$

'So as to praise God in their own language: Dialectal translations of Bible fragments in Slepo Sorbian new songbooks'

As mentioned, her presentation was made in a special dialect, Slepo, which is neither Upper nor Lower Sorbian, elsewhere to be heard only in a couple of villages in North Eastern Upper Lusatia. It is used actively as a mother tongue by only a few dozens of speakers who sing from Upper Lusatian evangelic songbooks and read an Upper Sorbian Protestant Bible. The language differs in many respects from the standard Upper Sorbian, from phonology to phraseology. Believers often note down words in their vernacular on the margins of printed pages. There are not many longer texts from the past of the dialect but some there are. These and the songbook as the regular space where the two languages confront were the topic Juliana Kaulfürstowa spoke of. While she used the local dialect for presentation, Juliana is also a fluent Czech speaker, which made the following discussion easier for most of the attendants. As it was apparent, Czech people are still well aware of the life and language of Lusatian Sorbs, including the extensive coal mining in their small region

\footnotetext{
Jan Stanislav Institute of Slavistics, Slovak Academy of Sciences, Bratislava.

5 Róbert Lapko, Juraj Feník, Jozef Jančovič, Jaroslav Rindoš, Peter Zubko, Peter Žeňuch Jánovo evanjelium: nový preklad a krátky komentár (Bratislava: Slavistický ústav Jána Stanislava, 2019). PDF available at www.slavu.sav.sk/publikacie/evanjelium.pdf.

6 Róbert Lapko, ed., K metodike nového prekladu Svätého Písma do slovenčiny [Notes on the methods applied in the new Slovak translation of the Holy Bible] (Vision Slovakia, mn, USA, 2016), $298 \mathrm{p}$.

7 The Sorbian Institute, Budyšin/Bautzen, Germany.
} 
demanding for the communities to be relocated which reduces dramatically the chances for their language to survive.

\section{Media}

'Some parameters of Czech Biblical style in later 16th century: Main differences in the NT of the Bible of Kralice and the Melantrich Bible'

PhDr. Robert Dittmann, Ph.D., ${ }^{8}$ specialises on the Bible of Kralice. He confronted it with another version, well established in its day in many respects, the Melantrich Bible. It was interesting to realize the Bible of Kralice that has shown its exceptional qualities throughout its four centuries was originally not much more than a marginal attempt of a minor religious group at the periphery of the Czech Kingdom. The edge was substantial for the Melantrich Bible published then in large quantities, enjoying the attention of the Imperial Throne as well as oecumenical support. The analysis of the language, however, demonstrated the linguistic qualities the translators at Kralice embedded in their version. These were finally to prove successful and to last for centuries.

The next contribution, though intended for versologists, was relevant to translators generally as the challenge of OT poetry is to be tackled with by translators anywhere:

'Syllable weight in earlier translating Psalms'

ThLic. Tomáš Matějec, Ph.D., ${ }^{9}$ as if brought back the evergreen issue of Czech versology, the question if syllable weight is fit for Czech. Obviously, no new solution to this once well circulated question was offered. Interesting, however, was to see how serious and sustained was experimenting with syllable weight in Czech poetry. Noble and meaningful as Biblical Psalms are, they requested a noble form, which used to be syllable weight for long centuries. The large company of experimenters includes experienced authors such as Comenius. Too often, however, additional metrical principles had to be involved. Being able to sing the psalms is what keeps translators and poets stimulated to try and set the Psalms in verse.

'A semantic bohemism "mięśny" (2 Cor. 3:3, Gr. бópкıvos) in relation to the issue of lexical dependence of the Bible of Gdansk on the Bible of Kralice'

Prof. dr hab. Tomasz Lisowski ${ }^{10}$ used Polish translations of the Greek adjective бópкıvoৎ to demonstrate how the Bible of Kralice influenced a Polish version of a comparable impact in Poland, the Protestant Bible of Gdańsk. Czech

8 Institute of Czech Language and Theory of Communication, Faculty of Arts, Charles University.

9 Department of Ecclesiastical History and Literary History, Catholic Theological Faculty, Prague.

10 Institute of Polish Philology, Adam Mickiewicz University, Poznań, Poland. 
translations of 2 Cor. 3:3 are far from ideal, especially if they insist on an adjective patterned by the Greek; and similar problems in a language with similar options are reflected in the Polish version. A living discussion followed.

\section{“Everyman's” Holy Scriptures: A New Testament by František Pollášek of 1791/1792'}

Doc. PhDr. Josef Bartoň, Th.D., ${ }^{2}$ turned attention to a remarkable translating achievement, still virtually unknown in wider scholarly circles.

František Pollášek (1757-1828) was a professor of Theological Faculty in Olomouc. Ministering as a priest, he soon realized that for the common man to understand and love Scriptures, the books had to speak in the language of their hearts. He was well qualified to translate the NT in such a language that sounded both dignified and naturally for any farmer.

Doc. Bartoň furnished many examples (in eight categories) where the way Prof. Pollášek put it sounded much clearer and commonplace than what the versions of the day offered. He contrasted it with the Czech Bible of 1778 (Durych - Procházka), almost contemporaneous with the Pollášek NT of 1791 (I.) - 1792 (II.). Some conversions he was bold enough to make, translators dared to do only more than 120 years later, some not before the present-day and, I admit as a Bible translator (sympathetic to that approach to translating), I would hesitate myself to make some conversions despite appreciating them. František Pollášek got ahead of his times considerably. It was apparent again that significant or revolutionary achievements do not need established Bible centres and respectable institutional support.

\section{Vetera}

The two mediaeval version sections (3 Vetera \& 4 Vetera) were open to young researchers to inform on the results of their ongoing researches.

'Selected issues of the development of Old Czech vocalism in the Leskovec-Dresden Bible (1365-1375)'

Mgr. Anastasija Rožkova ${ }^{8}$ demonstrated that vocalic shifts in Old Czech had different speed in various layers of the word stock as she differentiated endings, stems of grammar words and frequent items from other portions of the vocabulary. I can see an analogy to slow and unequal development in word stocks and other layers of language. It is advisable not to think of phonological changes as switching parameters to cause largescale reshuffling throughout the system. (Basic assumptions of modern generative phonologies as well as brief treatmens in textbooks tend to suggest such simplified views.) 


\section{'Linguistic specifics of the Second Revision of the Old Czech Bible version'}

Mgr. Hana Kreisingerová, Ph.D., ${ }^{11}$ has shown how Latin tenses were translated to Old Czech in the Second Revision of the Old Czech Bible. Czech used to render e.g. Lat. perfect with a former aorist, but what slowly emerged in translations was composite past such as it is today. Thanks to her differentiating statistics in various portions of the word stock, we can witness how much the different layers of vocabulary were affected by the composite past preference. $^{12}$

'On the language and authorship of the Martin Lupáč New Testament (ca. 1450)'

Mgr. et Mgr. Katarína Džunkovái3 discussed how much Martin Lupáč, a distinct Utraquist personality, actively affected the final form of the Utraquist revision of the Czech text of the NT emerging in 1430s. Martin Lupáč was no doubt erudite enough and an experienced author (despite writing more in Latin than in Czech) to cope well with the task. His achievement seems the more important as it makes a transition to the Fourth Revision of the Old Czech Bible which was to become later the text to be printed in the first Czech Bible incunabula. That is why his share deserves a more substantial evaluation.

\section{'A mystical concept of the Song of Songs in the Old Czech Bible'}

Bc. Anna Michalcová ${ }^{8}$ dealt with the character and origin of interpretive headings in Old Czech versions of the Song of songs. Whereas the Hebrew needs no headings as it provides enough clues as to who is the speaker, ${ }^{14}$ European languages including Czech have mostly to headline stanzas, which reveals if this poem on the love between a man and a woman is understood as between the Lord and Israel (common Jewish interpretation), Christ and Church (as common in Christians) or just the love itself. As the poem is eventful, the allegorical interpretation, cultivated and layered for centuries, makes a theological topic as it is. Bc. Michalcová collected and categorized headings from quite a few versions so the survey offered an interesting picture: While we might expect the Mediaeval Czech versions were concerned with nothing but the traditional allegorical approach established in churches from as early as Origenes, we would be mistaken. Apart from Christ and Church (into which

11 Department of Language Development, Czech Language Institute, Academy of Sciences.

12 The 2nd Revision of the Old Czech Bible consists of almost three dozens of textually varied manuscripts throughout a longer period. It is reasonable to distinguish at least an older and a younger stage.

13 Department of East European Studies, Faculty of Arts, Charles University.

14 Hebrew distinguishes genders in 2nd and 3rd person verbs and many pronouns as well as possessives which in suffixes to nouns are more frequent than possessive adjectives in Czech. Few common Hebrew sentences in the Hebrew Bible are neutral in gender. 
High Middle Ages projected Mary) we meet also the synagogue, and there are even versions with no headings at all, relying on the reader to conclude who is the speaker.

\section{'Initials in Old Czech Psalters'}

Mgr. Andrea Svobodová, Ph.D., ${ }^{11}$ Mgr. Kateřina Voleková, Ph.D., ${ }^{11}$ and Bc. Ondřej Batka ${ }^{11}$ pointed to a very specific issue the users of the modern critical editions rarely come across. The early (mostly Biblical) printed texts used to leave blanks for initial letters to be painted in by hand. The artist was somebody else and usually somewhere else than the printers. Who wrote the text or, later, who typeset it and saw the draft, knew what initial was to get in which blank on the page. The letter was noted down on the margin to be hardly noticeable for a common reader. It was only for the illuminator to find and paint it inside. Not infrequently, however, the clue was missing, or missed by the illuminator. He had then to guess it, which might be easy, but he might make a mistake. Modern editors have to identify and mark out such mistakes.

Listening to presentations, participating in the discussions and involving in conversations was rewarding and often revealing. I am sure the participants would welcome if this event could keep on being annual.

doi: 10.14712/23363398.2020.53 